УДК 637.1

\title{
Valorization of residual yoghurt whey by lactic acid production: An optimized process
}

\author{
Associate Prof. AÏCHA NANCIB ${ }^{1}$, Prof. NABIL NANCIB, \\ Master ABDENOUR AZZOUG, \\ Master AISSA ABED, Prof. HOCINE DABA \\ 1nancibaicha@yahoo.fr \\ Laboratory of Applied Microbiology, Ferhat Abbas University, Setif, Algeria \\ Emeritus Prof. JOSEPH BOUDRANT \\ Laboratory Reactions and Chemical Engineering (LRGP), UMR CNRS 7224, University of Lorraine, ENSAIA, \\ Vandoeuvre Cedex, 54505, France \\ DAOM ELLIE R. AMIROVA ${ }^{2}$ \\ ²eamirova@hotmail.com \\ Pacific College of Oriental Medicine, 7445 Mission Valley Road, San Diego, CA, 92108, USA \\ ITMO University, 191002, Lomonosov str., 9, Russia, St. Petersburg \\ $D$. Sc. TATIANA V. MELEDINA ${ }^{3}, P h$. $D$. OKSANA V. GOLOVINSKAYA \\ ${ }^{3}$ Meledina07@mail.ru \\ ITMO University, 191002, Lomonosov str., 9, Russia, St. Petersburg
}

\begin{abstract}
Waste valorization practices have attracted a significant amount of attention in recent years with the aim of managing waste in the most sustainable way. Food waste constitutes a largely under-exploited residue from which a variety of valuable chemicals can be derived. The operation in global yoghurt market provokes frequently the reject and withdrawn of yoghurt derivates out of shelf life. This work comprises a contribution on the valorisation of this high polluting waste of the dairy industry, based on the production of lactic acid using residual yoghurt whey as raw material. Response surface methodology (RSM) based on central composite design (CCD) was used to evaluate the effects of fermentation parameters for lactic acid production by Lactococcus lactis subsp. in batch experiments. The critical factors selected for the investigation were: sugars concentration $\left(X_{1}\right)$, yeast extract concentration $\left(X_{2}\right)$ and inoculum size $\left(X_{3}\right)$. The experimental results were fitted with a second order polynomial equation by a regression analysis and $93 \%$ of the variation could be predicted by the model. A maximum lactic acid production $(6.80 \mathrm{~g} / \mathrm{l})$ was obtained under following optimal conditions: sugars concentration $57 \mathrm{~g} /$, yeast extract concentration $10.8 \mathrm{~g} / \mathrm{l}$ and inoculum size $10 \%$. Moreover, the maximum of lactic acid production predicted by the model was $6.61 \mathrm{~g} / \mathrm{l}$. These results confirmed the validity of the model, and the experimental values were quite close to the predicted values.
\end{abstract}

Keywords: Lactococcus lactis subsp. Lactis, whey, lactic acid, design of experiments, fermentation.

Информация о статье

Поступила в редакцию 06.04.2016, принята к печати 08.07.2016

doi: $10.21047 / 1606-4313-2016-15-3-13-17$

Ссылка для цитирования

Nancib A., Nancib N., Azzoug A., Abed A., Daba H., Boudrant J., Amirova E. R., Meledina T. V., Golovinskaya O. V. Valorization of residual yoghurt whey by lactic acid production: An optimized process // Вестник Международной академии холода. 2016. № 3. C. 13-17.

\section{Валоризация остаточной йогуртной сыворотки при производстве молочной кислоты: оптимизированный процесс}

\author{
А. НАНСИБ ${ }^{1}$ Н. НАНСИБ, А. АЗЗОУГ, А. АБЕД, Х. ДАБА \\ Университет Ферхата Аббаса, Сетиф, Алжир \\ Д. БОУДРАНТ \\ Университет Лотарингии, Франичия \\ Э. Р. АМИРОВА \\ Тихоокеанский колледж восточной медицины, Сан-Диего, США \\ Университет ИТМО, Санкт-Петербург, Россия \\ Т. В. МЕЛЕДИНА, О. В. ГОЛОВИНСКАЯ \\ Университет ИТМО, Санкт-Петербург, Россия
}

Валоризация отходов при их обработке наиболее устойчивым методом стала более актуальной темой в последние годы. Пищевые отходы, из которыхмогут быть получены разнообразные ценные химические вещцества, 
значительно недоиспользуемы. На мировом рынке йогуртной промышленности, йогуртные производые часто неприемлемы и снижают срок годности. В этой работе изучена валоризация этих высоко загрязняющих отходов молочной промышленности на основе производства молочной кислоты с использованием остаточной йогуртной сыворотки в качестве сырья. Методология отклика поверхности (МПО) основанная на конструкции центральной составной (КЦС) были использованы для оценки последствий параметров ферментации для производства молочной кислоты Lactococcus Lactis в пакетных экспериментах. Критические факторы, выбранные для исследования были: концентрация сахара $\left(X_{p}\right)$, концентрация дрожжжевой экстракт $\left(X_{2}\right)$ и размер посевной $\left(X_{3}\right)$. Экспериментальные результаты были оснащены полиномиального уравнения второго порядка с помощью регрессионного анализа и $93 \%$ вариация могла быть предсказана с помощью модели. Максимальное производство молочной кислоты (6,80 2/л) было получено при следующих оптимальных условий: концентрации сахаров 57 г/ л, дрожжевой экстракт концентрации 10,8 г/л и размер инокулята $10 \%$ Кроме того, максимум производства молочной кислоты, предсказанной модели составляет 6,61 г/л. Эти результаты подтвердили применимость модели, и экспериментальные значения были весьма близки к предсказанным значениям.

Ключевые слова: Lactococcus лактис подвид Lactis, сыворотка, молочная кислота, планирование эксперимента, брожение.

\section{Introduction}

The out-of-date products are the pet peeve of the bosses of all the grocery stores. Besides reducing the margin of the company, these products arrived in their best-before date classify these business companies among the big producers of biowaste. Biowaste containing large amounts of organic matter like yoghurt is a valuable commodity. The future of yoghurt production, considering the environmental implications of increasing manufacture, involves the treatment of the dairy fermented products out of shelf life. The withdrawn and rejects from market of damaged yoghurts and drinking yoghurts or those over their sell-by date, create an important amount of human foodstuff waste which is unsuitable for sale. Yoghurt is a dairy product sweetened with high levels of conventional added sugars such as sucrose and glucose [1]. However, as far as we know, until now there are only a few systematic reports on residual yoghurt whey fermentation for production of lactic acid by bacteria [2].

Lactic acid is a most important product that has attracted a great deal of attention due to its widespread applications, mainly in food, pharmaceutical, textile, leather, chemical, cosmetic, and polymer industries. Presently, almost all lactic acid produced worldwide comes from the fermentative production [3-6]. Lactic acid production has been studied with various raw materials such as wheat straw [7], wheat bran [8], corn stover [9], starch [10], potato peal waste [11], cashew apple juice [12], and rice bran [13]. However, their potential use is limited by laborious steps such as simultaneous hydrolysis and fermentation with saccharifying enzymes [14].

Yoghurt whey is proposed here to be used as a source for lactic acid fermentation. The present work was, therefore, carried out to optimize the process conditions for efficient sugars conversion in yoghurt whey to lactic acid by Lactococcus lactis subsp. lactis by employing a central composite design (CCD) of response surface methodology (RSM).

\section{Materials and methods}

\section{Microorganism}

The Lactococcus lactis subsp. lactis strain, isolated from Algerian raw camel milk, was maintained frozen (in $20 \% \mathrm{v} / \mathrm{v}$ glycerol at $-20^{\circ} \mathrm{C}$ ). The strain was cultured in the Eliker broth.

\section{Yoghurt whey preparation}

Yoghurts expired date were previously mixed in order to obtain yoghurt whey by heat treatment at $94{ }^{\circ} \mathrm{C}$ for $20 \mathrm{mn}$. The mixture was centrifuged at $4,000 \mathrm{x}$ for $20 \mathrm{~min}$ at $4{ }^{\circ} \mathrm{C}$ and filtration of the supernatant through a $0,45 \mu \mathrm{m}$ filter. Yoghurt whey was used essentially as the carbon source in the fermentation medium. Immediately prior to each experiment, an appropriate quantity yoghurt whey was diluted to desired concentration of sugars. Table 1 summarizes the characteristics of yoghurt whey used in fermentation experiments.

Table 1

Characteristics of yoghurt whey used in fermentation experiments

\begin{tabular}{|l|c|c|c|}
\hline \multicolumn{1}{|c|}{ Characteristics } & $\begin{array}{c}\text { Protein } \\
\text { concentra- } \\
\text { tion } \\
\left(\mathrm{gl}^{-1}\right)\end{array}$ & $\begin{array}{c}\text { Total } \\
\text { sugars } \\
\left(\mathrm{gl}^{-1}\right)\end{array}$ & $\begin{array}{c}\mathrm{pH} \\
\text { (units) }\end{array}$ \\
\hline Raw yoghurt whey & 9.4 & 140 & 4.2 \\
\hline Yoghurt whey used as medium & 1.3 & $33.18-66.82$ & 6.0 \\
\hline
\end{tabular}

\section{Culture and fermentation conditions}

The inoculum was prepared by transferring glycerol stock culture $(1 \mathrm{ml})$ to an Erlenmeyer flask containing $100 \mathrm{ml}$ of Elliker medium and incubated at $33.5^{\circ} \mathrm{C}$ for $4 \mathrm{~h}$ (time to needed for microorganism to reach the exponential growth phase) on a rotary shaker (New Brunswick Scientific) at $200 \mathrm{rpm}$. Initial $\mathrm{pH}$ of medium was ajusted to 6 by adding $\mathrm{NaOH}(1 \mathrm{~N})$.

\section{Analytical methods}

The content of sugars was determined by using phenol sulphuric acid, as described by Dubois et al. (1956) [15]. The following experiemnts were carried out in triplicate.

Protein content was determined according to Bradford [16] using bovine serum albumin as standard.

The amount of lactic acid in fermentation broth was determined by AOAC methode [17]. One $\mathrm{ml}$ of phenolphthalein indicator $(0.5 \%$ in $5 \%$ alcohol $)$ was added to $25 \mathrm{ml}$ of culture broth. This was titrated with $0.1 \mathrm{M} \mathrm{NaOH}$ for the appearance of pink colour. The titratable acidity was calculated as 
percentage of lactic acid. Each millilitre of $1 \mathrm{~N} \mathrm{NaOH}$ is equivalent to $90.08 \mathrm{mg}$ of lactic acid.

\section{Central Composite Design}

The yoghurt whey was considered as the basal medium, and used for optimization by response surface methodology (RSM) using Central Composie Design (CDD). The level of three variables: sugars concentration, yeast extract concentration and inoculum size chosen for this study were optimized by the experimental plan. Design of the experiments was done with Minitab Statistical Software version 16 (Minitab Inc, State College, PA). As shown in Table 2 the three factors were designated as $X_{1}, X_{2}, X_{3}$ and prescribed into five differents levels $(-\alpha,-1,0,+1,+\alpha)$. A set of 20 experiments were carried out. All variables were taken at a central coded value considered as zero. The minimum and the maximum ranges of variables were investigated and the full experimentatl plan with respect of their values in actual and coded forme is listed in Table 3. For predicting the optimal point, a secondorder polynomial model was fitted to correlate relationship between independent variables and response (lactic acid concentration). For the three factors, the equation is

$$
\begin{aligned}
Y=\beta_{0} & +\beta_{1} X_{1}+\beta_{2} X_{2}+\beta_{3} X_{3}+\beta_{12} X_{1} X_{2}+\beta_{13} X_{1} X_{3}+ \\
& +\beta_{23} X_{2} X_{3}+\beta_{11} X_{1}^{2}+\beta_{22} X_{2}^{2}+\beta_{33} X_{3}^{2},
\end{aligned}
$$

where $Y$ is the predicted response; $\beta_{0}$ is model constant; $\beta_{1}$, $\beta_{2}$ and $\beta_{3}$ linear coefficients; $\beta_{12}, \beta_{23}, \beta_{13}$ interaction coefficients; $\beta_{11}, \beta_{22}, \beta_{33}$ squared coefficients.

The quality of fit of the polynomial model equation was expressed by the coefficient of determination $R^{2}$.

\section{Results and discussion}

\section{Optimization of lactic acid production}

The results of CDD experiments for studying the effects of three independent variables: sugars, yeast extract and inoculum size are presented in the Table 4 along with the mean predicted and observed response. A $2^{3}$ factorial central composite experimental design with six axial points and six replications at the center point leading to a total number of 20 experiments was employed for the optimization of the parameters. The agreement between the lactic acid predicted by the model and the experimental data is very strong, with a difference less than 1 .

By applying multiple regression analysis to the experimental data, the following second order polynomial equation was found to represent the lactic acid production adequately.

$$
\begin{gathered}
Y(\text { Lactate } \mathrm{g} / \mathrm{l})=6.54+0.30 X_{1}+0.56 X_{2}+0.16 X_{3}- \\
-0.25 X_{1}^{2}-0.36 X_{2}^{2}-0.21 X_{3}^{2}-0.03 X_{1} X_{2}+ \\
+0.03 X_{1} X_{3}-0.4 X_{2},
\end{gathered}
$$

where $Y$ is the predicted response and $X_{1}, X_{2}, X_{3}$ are coded levels of the factors for lactic acid production.

The regression equation (Eq. 2) showed that lactic acid production $(Y)$ is a function of the sugars concentration $\left(X_{1}\right)$; yeast extract concentration $\left(X_{2}\right)$ and inoculum size $\left(X_{3}\right)$.

The goodness of the fit of the model was checked by the determination coefficient $\left(R^{2}\right)$. The coefficient of determination is an important tool in determining the degree of linear correlation of variables in regression analysis. It

provides a measure of how much variability in the observed response values can be explained by the experimental factors and their interactions. The coefficient of determination $\left(R^{2}\right)$ was calculated to be 0.93 , indicating that $93 \%$ of the variability in the response could be predicted by the model. The closer the $R^{2}$ is to 1 , the stronger the model and the better it predicts the response [18]. Chauhan and Gupta [19] reported $R^{2}$ greater than $75 \%$ as acceptable for fitting a model.

The significance of the fit of the lactic acid model was assessed by performing analysis of variance (ANOVA). A model $F$-value of 15.10 and a very low probability value $(P$-value $=0.000)$ imply significant model fit. The Lack of Fit $F$-value of 1.17 implies that there is insignificant lack of fit. The Lack of Fit $P$ value of 0.434 implies that there is only $43.4 \%$ chance that the Lack of Fit $F$-value could occur due to noise (Table 5). The significance of each coefficient was determined by student's $t$-test and $p$-values which are listed in Table 6. The larger the magnitude of the $t$-value and the smaller the $p$-value, the more significant is the corresponding coefficient [20,21]. The $P$-values were used as a tool to check the significance of each coefficient, which also indicates the interaction effects between each independent variable [22]. The regression of all the linear term and quadratic coefficients were significant.

Table 2

\section{Concentration ranges of the three components used in Central Composite Design}

\begin{tabular}{|c|c|c|c|c|c|c|}
\hline \multirow{2}{*}{ Variables } & \multirow{3}{*}{ Codes } & \multicolumn{5}{|c|}{ Coded levels } \\
\cline { 3 - 7 } & & $-\alpha$ & -1 & 0 & +1 & $+\alpha$ \\
\hline & & & & & & \\
Sugars (g/l) & $X_{1}$ & 33.18 & 40 & 50 & 60 & 66.82 \\
Yeast extract (g/l) & $X_{2}$ & 1.59 & 5 & 10 & 15 & 18.41 \\
Inoculum size (\%) & $X_{3}$ & 1.95 & 4 & 7 & 10 & 12.04 \\
\hline
\end{tabular}

$\alpha=1,682$

Table 3

Experimental plan for optimization of lactic acid production using response surface methodology

\begin{tabular}{|c|c|c|c|c|c|c|}
\hline \multirow{2}{*}{ Run } & \multicolumn{2}{|c|}{ Sugars $\left(X_{1}\right)$} & \multicolumn{2}{c|}{ Yeast extract $\left(X_{2}\right)$} & \multicolumn{2}{c|}{$\begin{array}{c}\text { Inoculum size } \\
\left(X_{3}\right)\end{array}$} \\
\cline { 2 - 7 } & Actual & Coded & Actual & Coded & Actual & Coded \\
\hline 1 & 40 & -1 & 5 & -1 & 4 & -1 \\
2 & 60 & +1 & 5 & -1 & 4 & -1 \\
3 & 40 & -1 & 15 & +1 & 4 & -1 \\
4 & 60 & +1 & 15 & +1 & 4 & -1 \\
5 & 40 & -1 & 5 & -1 & 10 & +1 \\
6 & 60 & +1 & 5 & -1 & 10 & +1 \\
7 & 40 & -1 & 15 & +1 & 10 & +1 \\
8 & 60 & +1 & 15 & +1 & 10 & +1 \\
9 & 33.18 & $-\alpha$ & 10 & 0 & 7 & 0 \\
10 & 66.82 & $+\alpha$ & 10 & 0 & 7 & 0 \\
11 & 50 & 0 & 1.59 & $-\alpha$ & 7 & 0 \\
12 & 50 & 0 & 18.41 & $+\alpha$ & 7 & 0 \\
13 & 50 & 0 & 10 & 0 & 1.954 & $-\alpha$ \\
14 & 50 & 0 & 10 & 0 & 12.046 & $+\alpha$ \\
15 & 50 & 0 & 10 & 0 & 7 & 0 \\
16 & 50 & 0 & 10 & 0 & 7 & 0 \\
17 & 50 & 0 & 10 & 0 & 7 & 0 \\
18 & 50 & 0 & 10 & 0 & 7 & 0 \\
19 & 50 & 0 & 10 & 0 & 7 & 0 \\
20 & 50 & 0 & 10 & 0 & 7 & 0 \\
\hline
\end{tabular}


Table 4

Experimental and predicted values of lactic acid production recorded in the experimental set up of RSM

\begin{tabular}{|c|c|c|c|}
\hline \multirow{2}{*}{ Run } & \multicolumn{3}{|c|}{ Lactic acid (g/l) } \\
\cline { 2 - 4 } & Actual & Predicted & Difference \\
\hline 1 & 4.45 & 4.29 & -0.16 \\
2 & 4.95 & 4.88 & 0.07 \\
3 & 6.43 & 6.26 & 0.17 \\
4 & 6.93 & 6.74 & 0.19 \\
5 & 5.44 & 5.35 & 0.09 \\
6 & 6.18 & 6.07 & 0.11 \\
7 & 5.94 & 5.73 & 0.21 \\
8 & 6.45 & 6.33 & 0.12 \\
9 & 5.10 & 5.33 & -1.23 \\
10 & 6.18 & 6.33 & -0.15 \\
11 & 4.45 & 4.56 & -0.11 \\
12 & 6.18 & 6.44 & -0.26 \\
13 & 5.44 & 5.65 & -0.21 \\
14 & 6.05 & 6.21 & -0.16 \\
15 & 6.93 & 6.54 & 0.39 \\
16 & 6.68 & 6.54 & 0.14 \\
17 & 6.68 & 6.54 & 0.14 \\
18 & 6.43 & 6.54 & -0.11 \\
19 & 6.43 & 6.54 & -0.11 \\
20 & 6.18 & 6.54 & -0.36 \\
\hline
\end{tabular}

ANOVA for response surface quadratic model

\begin{tabular}{|c|c|c|c|c|c|}
\hline Source & DF & $\begin{array}{c}\text { Sum of } \\
\text { square }\end{array}$ & $\begin{array}{c}\text { Mean sum } \\
\text { of square }\end{array}$ & $F$-Value & $P>F$ \\
\hline Model & 9 & 10.1342 & 1.12602 & 15.10 & 0.000 \\
\hline $\begin{array}{c}\text { Residual } \\
\text { (error) }\end{array}$ & 10 & 0.7455 & 0.07455 & - & - \\
\hline Lack of Fit & 5 & 0.4018 & 0.08035 & 1.17 & 0.434 \\
\hline Pure Error & 5 & 0.3437 & 0.06875 & - & - \\
\hline Cor total & 19 & 10.8797 & - & - & - \\
\hline
\end{tabular}

Table 6

\section{Results of regression analysis of the second-order polynomial model for optimization of lactic acid production}

\begin{tabular}{|c|c|c|c|c|}
\hline Factor & $\begin{array}{c}\text { Coefficient } \\
\text { estimate }\end{array}$ & $\begin{array}{c}\text { Standard } \\
\text { error }\end{array}$ & $t$-Ratio & $P$-Value \\
\hline Intercept & 6.54 & 0.111 & 58,76 & 0.000 \\
\hline$X_{1}$ & 0.30 & 0.073 & 4.030 & $0.002^{*}$ \\
\hline$X_{2}$ & 0.56 & 0.073 & 7.57 & $0.000^{* *}$ \\
\hline$X_{3}$ & 0.16 & 0.073 & 2.25 & $0.048^{*}$ \\
\hline$X_{1} X_{2}$ & -0.03 & 0.096 & -0.29 & $0.77^{* * *}$ \\
\hline$X_{1} X_{3}$ & 0.03 & 0.096 & 0.32 & $0.75^{* * *}$ \\
\hline$X_{2} X_{3}$ & -0.40 & 0.096 & -4.13 & $0.002^{*}$ \\
\hline$X_{1}^{2}$ & -0.25 & 0.071 & -3.50 & $0.006^{*}$ \\
\hline$X_{2}^{2}$ & -0.36 & 0.071 & -5.09 & $0.000^{* *}$ \\
\hline$X_{3}^{2}$ & -0.21 & 0.071 & $-2,98$ & $0.014^{*}$ \\
\hline
\end{tabular}

\footnotetext{
* Significant at $P<5 \%$.

** Very significant.

*** Not significant.
}

Values of $P$ less than 0.05 indicate the model terms are significant. From the regression model of lactic acid concentration, the model terms $X_{1}, X_{2}, X_{3}, X_{1}^{2}, X_{2}^{2}, X_{3}^{2}$ were significant with a probability of $95 \%$. The term $X_{2} X_{3}$ was also significant indicating that there was interaction between yeast extract concentration and inoculum size. The results show the importance of the yeast extract on lactic acid production. Lactic acid bacteria are known for their fastidious nutritional requirements [23, 24]. Most Lactic acid bacteria species require complex nutrients, including amino acids, peptides, nucleotides, and vitamins, for their growth because they lack many biosynthetic capabilities $[25,26]$. Nitrogen is very crucial for cell growth [27], and its optimization would be relevant for lactic acid production [28], which is a growth associated product [29]. The interaction between the terms $X_{1}, X_{2}$ and $X_{1}, X_{3}$, however, had no significant effect on the lactic acid produced during fermentation (Table 6).

\section{Validation of the Model}

The statistical model was validated by comparing model predicted results with those of repeated experiments carried out at the optimized conditions: sugars concentration $57 \mathrm{~g} / 1$ $\left(X_{1}\right)$; yeast extract concentration $10.8 \mathrm{~g} / 1\left(X_{2}\right)$ and inoculum size $10 \%\left(X_{3}\right)$. The mean of the results obtained from three replications was close to that predicted by the model (the predict response for lactic acid production was $6.61 \mathrm{~g} / \mathrm{l}$ and the actual response was $6.80 \mathrm{~g} / \mathrm{l}$ ) thus showing validity.

\section{Conclusion}

Yoghurt whey, a waste material, has been revealed as a suitable and direct substrate to lactic acid production by Lactococcus lactis subsp. The central composite design and response surface methodology enable the determination of optimal operating conditions for obtaining greater lactic acid production. The validity of the model was proved by fitting the values of the variables in the model equation and by actually carrying out the experiment at those values of the variables. The methodology as a whole proved to be quite adequate for the design and optimization of the process.

\section{References}

1. Tiamine, A. Y., Robinson, R. K., 1999. Yoghurt: science and technology. 2nd ed. Cambridge, England: Woodhead Publishing.

2. Alonso, S., Herrero M., Rendueles M. and Diaz, M., 2014. Physiological heterogeneity in Lactobacillus casei fermentations on residual yoghurt whey. Process Biochemistry, 49, 732-739.

3. Abdel-Rahman, M. A., Tashiro, Y., Sonomoto, K., 2011. Lactic acid production from lignocellulose derived sugars using lactic acid bacteria: overviewand limits. J Biotechnol, 156, 286-301.

4. Mussatto, S. I., Fernandes, M., Mancilha, I. M., Roberto, I., 2008. Effects of medium supplementation and $\mathrm{pH}$ control on lactic acid production from brewer's spent grain. Biochem. Eng. $J, 40,437-444$.

5. Wee, Y. J., Ryu, H. W., 2009. Lactic acid production by Lactobacillus sp. RKY2 in a cellrecycle continuous fermentation using lignocellulosic hydrolyzates as inexpensive raw materials. Bioresour. Technol, 100, 4262-4270.

6. Kadam, S. R., Patil, S. S., Bastawde, K. B., Khire, J. M., Gokhale, D. V., 2006. Strain improvement of Lactobacillus delbrueckii 
NCIM 2365 for lactic acid production. Process Biochem, 41 , $120-126$.

7. Zhang Y., Chen X., Luo J., Q. B., Wan Y., 2014. An efficient process for lactic acid production from wheat straw by a newly isolated Bacillus coagulans strain IPE22. Bioresour Technol, 158, 396-399.

8. Li Z., Han L., Ji Y., Wang X., Tan T., 2010. Fermentative Production of L-Lactic Acid from Hydrolysate of Wheat Bran by Lactobacillus rhamnosus. Biochemical Engineering Journal, 49, 138-142.

9. Cui F., Li Y., Wan C., 2011. Lactic acid production from corn stover using mixed cultures of Lactobacillus rhamnosus and Lactobacillus brevis. Bioresour. Technol, 102, 1831-1836.

10. Wakai, S., Yoshie, T., Asai-Nakashima, N., Yamada R., Ogino, C., Tsutsumi, H., Hata, Y., Akihoko, K., 2014. L-lactic acid production from starch by simultaneous saccharification and fermentation in a genetically engineered Aspergillus oryzae pure culture. Bioresour Technol, 173, 376-383.

11. Liang, S., McDonald, A. G., Coats, E. R., 2014. Lactic acid production with undefined mixed culture fermentation of potato peel waste. Waste Manage, 34, 2022-2027.

12. Silveira, M. S., Fontes, C. P., Guilherme, A. A., Fernandes, F. A., Rodrigues, S., 2012. Cashew apple juice as substrate for lactic acid production. Food Bioprocess Technol, 5, 947-953.

13. Li Z., Lu, J., Yang Z., Han L., Tan T., 2012. Utilization of White Rice Bran for Production of L-Lactic Acid. Biomass and Bioengy, 39, 53-58.

14. Bayitse, R., 2015. Lactic Acid Production from Biomass: Prospect for Bioresidue Utilization in Ghana: Technological Review. International Journal of Applied Science and Technology, 5 (1), 164-174.

15. Bradford, MM., 1976. A rapid and sensitive method for the quantification of microgram quantities of protein utilizing the principle of dye-binding. Analytical Biochemistry, 72, 248-54.

16. Dubois, M., Gilles, K. A., Hamilton, J. K., Rebers, P. A and Smith, F., 1956. Colorimetric method for determination of sugars and related substances. Analytical Chemistry, 28, 350-356.

17. AOAC, 1980. Official Methods of Analysis (13th ed.) Association of Official Analytical Chemists. Washingon D. C. pp. 23-34.

18. Cochran, W. G., Cox, G. M., 1957. Experimental Designs. 2nd edition. New York: John Wiley \& Sons, Inc. 346-354.

19. Chauhan, B., Gupta, R., 2004. Application of statistical experimental design for optimization of alkaline protease production from Bacillus sp RGR-14. Process Biochem, 39, 2115-2122.
20. Suzuki, G. T., Macedo, J. A., Macedo, G. A., 2011. Medium composition influence on Biotin and Riboflavin production by newly isolated Candida sp. Brazilian Journal of Microbiology, 42, 1093-1100.

21. Li, X. Y., Liu, Z. Q., Chi, Z. M., 2008. Production of phytase by a marine yeast Kodamaea ohmeri BG3 in an oats medium: optimization by response surface methodology,» Bioresource Technology, 99, 14, 6386-6390.

22. Lanka, S., Latha, J. N. L., 2015. Response surface methodology as a statistical tool for fermentation media optimization in lipase production by palm oil mill effluent (POME) isolate Emericella nidulans NFCCI 3643. International Journal of Innovative Research in Science, Engineering and Technology, 4 (4), 2534-2545.

23. Vera Pingitore, E. V., Hebert, E. M., Sesma, F., Nader-Macias, M. E., 2009. Influence of Vitamins and Osmolites on Growth and Bacteriocin Production by Lactobacillus sali-varius CRL 1328 in a Chemically Defined Medium. Canadian Journal of Microbiology, 55, 304-310.

24. Letort, C., Juillard, V., 2001. Development of a Minimal Chemically Defined Medium for the Exponential Growth of Streptococcus thermophilus. Journal of Applied Microbiology, 91, 1023-1029.

25. Litchfield, J. H., 2009. Lactic acid,microbially produced. In: SchaechterMosel O, editor. Encyclopedia of microbiology. Oxford: Academic Press; p. 362-72.

26. Singh, S. K., Ahmed, S. U., Pandey, A., 2006. Metabolic engineering approaches for lactic acid production. Process Biochem, 41,991-1000.

27. Schepers, A. W., Thibault, J., Lacroix, C., 2002. Lactobacillus helveticus growth and lactic acid production during $\mathrm{pH}-$ controlled batch cultures in whey permeate/yeast extract medium. Part I. Multiple factor kinetic analysis, Enzyme Microb. Technol, 30, 176-186.

28. Nancib, A., Nancib, N., Meziane-Cherif, D., Boubendir, A., Fick, M., Boudrant, J., 2005. Joint effect of nitrogen sources and $B$ vitamin supplementation of date juice on lactic acid production by Lactobacillus casei subsp. rhamnosus. Bioresource Technology, 96, 63-67.

29. Wee, Y. J., Ryu, H. W., 2009. Lactic acid production by Lactobacillus sp. RKY2 in acell-recycle continuous fermentation using lignocellulosic hydrolyzates asinexpensive raw materials. Bioresource Technol, 100, 4262-4270.

\section{$\equiv$}

INTERNATIONAL CONFERENCE Ammonia and $\mathrm{CO}_{2}$

Refrigeration Technologies

May 11-13, 2017, Ohrid, Republic of Macedonia

IIR Commission B2 with B1 and D1

http://www.mf.edu.mk/web ohrid2017/ohrid-2017.html
The topics of the conference are: design of modern ammonia and new $\mathrm{CO}_{2}$ systems and technological innovations, improving energy efficiency, various applications, technical guidelines and safety regulations. It is very clear: by using more ammonia and $\mathrm{CO}_{2}$ refrigerants, we are employing environmentally friendly technologies. 